\title{
DESIGN OF LEARNING MATERIALS ON CIRCLE BASED ON MATHEMATICAL COMMUNICATION
}

\author{
Cita Dwi Rosita ${ }^{1}$, Tri Nopriana ${ }^{* 2}$, Isna Silvia ${ }^{3}$ \\ ${ }^{1,2,3}$ Universitas Swadaya Gunung Djati
}

\begin{tabular}{l} 
Article Info \\
\hline Article history: \\
Received Dec 15, 2018 \\
Revised Jan 26, 2019 \\
Accepted Jan 28, 2019 \\
\hline
\end{tabular}

Keywords:

Didactical Design Research

Circle

Learning Obstacle

Mathematical Communication

\begin{abstract}
Mathematical communication skills is an important role in mathematics learning. However, the importance of mathematical communication skills has not been fully realized in learning, especially circle material. Design a learning material based on mathematical communication is one way to develop this ability. The preliminary study produced the findings of an epistemological learning obstacle so that students' mathematical communication skills were still in the low category. This study aimed to analyze learning obstacle and designing learning materials based on the material mathematical communication circle. This study is design research that contained two stages of Didactical Design Research (DDR), didactic situation and metapedadidactional stage. Research result obtained are students difficulties in relating the material defining elements of the circle with their own language, identifying circle elements that were known and explaining through pictures, calculating the circumference and distance of circular objects based on problems, calculating the surface area of circular objects based on the problems, and rearrange the formula which states the relationship of circle elements. To solve that learning obstacle, we recommend some learning trajectory in a circle that useful for teachers. This design of learning material is valid and practical to implement in the classroom.
\end{abstract}

Copyright $@ 2019$ IKIP Siliwangi. All rights reserved.

\section{Corresponding Author:}

Tri Nopriana,

Departement of Mathematics Education,

Universitas Swadaya Gunung Djati,

Jl. Pemuda No.32, Cirebon, Indonesia

Email: trinopriana@unswagati.ac.id

\section{How to Cite:}

Rosita, C. D., Nopriana, T., \& Silvia, I. (2019). Design of learning materials on circle based on mathematical communications. Infinity, 8(1), 87-98.

\section{INTRODUCTION}

Mathematical communication skills are one of five abilities recommended by the National Council of Teachers of Mathematics (Hiebert, 2003). This is in line with Baroody's (1993), there are two important reasons why mathematical communication is one of the focuses on mathematics learning. First, mathematics is basically a language for mathematics itself. Second, learning and teaching mathematics are social activities that involve at least two parties, namely teachers and students. In addition, it was also strengthened by Minister of Education and Culture Regulation No.58 at 2014 which states 
that the purpose of mathematics learning is to communicate ideas, reasoning, and be able to compile mathematical evidence by using complete sentences, symbols, tables, diagrams or other media to clarify the situation or problem. According to Greenes \& Schulman (1996), mathematical communication is (1) a central force for students in formulating concepts and strategies; (2) capital of success for students towards approaches and solutions in mathematical exploration and investigation; (3) a forum for students to communicate with their friends to obtain information, share thoughts and discoveries, brainstorm, assess and sharpen ideas to convince others. Based on the explanation, it can be said that mathematical communication skills are mathematical abilities that must be realized in mathematics learning.

Geometry is a branch of mathematics in the scope of learning material in schools. In our environtment, geometry can be found on objects in the form of spheres, tubes, boxes, lines, circles and so on. According to Bobango (Abdussakir, 2012) states that the purpose of geometry learning is students gain confidence about their mathematical abilities, become good problem solvers, can communicate mathematically, and can reason mathematically. In line with that, Walle \& Jhon (2001) suggested the reason for the importance of studying geometry including geometry being able to provide more complete knowledge about the world and play an important role in learning other concepts in mathematics learning. Based on the description above, it can be concluded that geometry is very important to learn, to foster the ability, and to communicate a mathematical idea. In connection with that, one of the materials in the scope of geometry in the eighth grade of junior high school that needs attention is the topic of the circle. The basic competencies that must be achieved by the eighth grade students on the topic of circle are students required to be able to express a description of the circle material that has been studied using their own language, explain the concept of broad and circumferential circles with real objects or images, connect a real situation about the circle into a mathematical model, and formulate definitions and generalizations of the relation of the center angle, bow length, and the area of the circle's section.

However, the importance of mathematical communication skills has not been fully realized in mathematics learning. Based on Horizon Research Center, Inc. (Tiffani, Surya, Panjaitan, \& Syahputra, 2017) suggests that at the junior high school level, student achievement related to problem-solving abilities, reasoning abilities, and communication skills in helping students to think mathematically is only $30 \%$. This is in line also as expressed by Munawaroh, Rohaeti, \& Aripin (2018) the percentage of student error in solving the problem of mathematical communication is equal to $38 \%$ at inappropriate data category, $34 \%$ at inappropriate procedure category, and $26 \%$ at omitted data category. Based on some of these explanations, it shows that mathematical communication skills have not been realized in the learning of mathematics, including in circle material. One of the causes is due to the learning barriers experienced by students. Students find it difficult to explain a mathematical idea related to circles with pictures, construct conjectures, and relevant generalizations of the circle's concepts. Learning barriers here are learning barriers commonly known as the epistemological learning obstacle Sulistiawati, Suryadi, \& Fatimah (2015) explained the cause of the epistemological learning obstacle is due to a lack of conformity of teaching materials presented to students with the condition of students in learning mathematics material. One way that is thought to be able to overcome the epistemological learning obstacle is by designing a learning materials. This is in line with Rosita (2016), who argued that educators should provide and develop learning materials that are in accordance with the characteristics and social environment of students.

In this study, the learning materials that will be designed are printed learning materials in the form of modules. Learning materials that are designed in the form of 
modules can help students to understand mathematical concepts independently with minimal assistance from teachers, because the material is arranged based on student's learning obstacle. The design of learning materials is thought to be a solution for building students' mathematical communication skills in mathematics learning. The research that supports this solution is the research conducted by Rosita, Nopriana, \& Dewi (2017), arguing that a learning material design can complete the ability of mathematical understanding both classical and individual. Noto, Pramuditya, \& Fiqri (2018) stated that the limit learning material for algebraic functions based on mathematical understanding can minimize learning obstacle after being implemented. The previous research shows that students' mathematical abilities can be built with the didactical design in the form of learning materials arranged by the teacher. Therefore, the purpose of this study is to design Circle learning materials that develop mathematical communication skills and learning trajectories to understand Circle material.

\section{METHOD}

This study uses a qualitative method in the form of didactical design research. Didactical Design Research (DDR) which consists of three phases, namely the didactic situation analysis before learning, metapedadidactic analysis, and retrospective analysis (Suryadi, 2013). The stages carried out in this research are the didactic situation analysis stage before learning and the metapedadidactic analysis phase. Didactical situation analysis phase before learning in the form of extracting information about learning obstacle material circles and formulating Anticipatory Didactical Pedagogical (ADP) as a framework for learning materials. Meanwhile, the metapedadidactic phase is the implementation of learning materials and the preparation of learning trajectories related to circle material.

Subjects in this study were 47 students of Majalengka 6th Junior High School which was divided into two groups, namely the subject for extracting information about learning obstacle, circle material and subject for the implementation of learning materials. Information gathering about learning obstacle was carried out for grade IX students who had already received circle material and the implementation of learning materials was done for class VIII students who had not studied circle material.

Data collection techniques used in this study are triangulation techniques. The combination of techniques used in this study is tests, interviews, and questionnaires. The instrument tests used was a mathematical communication ability test questions for learning circle material learning obstacle information, interviews are used to track data that is not obtained through tests. Module validation questionnaire, and module practical questionnaire for teachers and students given to test the validity and practicality of modules that have been made used.

\section{RESULTS AND DISCUSSION}

\subsection{Learning Obstacle and Didactical Situation Related to Circle Material}

The stage of didactical situation analysis before learning are students' learning obstacle analysis on circle related to their mathematical communication. Grouped learning obstacle then find a solution to overcome the learning obstacle. The solution is to design learning materials based on learning obstacle related to the material in the eighth grade of junior high school which will be included in the learning materials using the following 
didactical situations. The results of the analysis of the learning obstacle and didactical situation were explained at Table 1, Table 2, and Table 3.

Table 1. Learning Obstacle Related to Circle Element

\begin{tabular}{|c|c|c|}
\hline Number & Didactical Situation & Didactic Anticipation \\
\hline 1 & $\begin{array}{l}\text { A student divides the area in a circle } \\
\text { using } 6 \text { bowstrings. How many areas can } \\
\text { the student make? Draw the circle area } \\
\text { in question! }\end{array}$ & $\begin{array}{l}\text { A student divides the area in a circle using } \\
6 \text { bowstrings. How many areas can the } \\
\text { student make? Draw the circle area in } \\
\text { question like the description of the image } \\
\text { shown below. } \\
\text { The maximum } \\
\text { busur } 1 \text { bowstring is } 2 \\
\text { area. }\end{array}$ \\
\hline 2 & $\begin{array}{l}\text { In the picture below, the point } \mathrm{O} \text { is the } \\
\text { center point of the circle, points } \mathrm{C}, \mathrm{D}, \mathrm{E} \text {, } \\
\mathrm{F}, \mathrm{G}, \mathrm{I} \text { and } \mathrm{J} \text { lie on the circle and the } \\
\text { point } \mathrm{H} \text { lies inside the circle. } \mathrm{CD} \text { and } \mathrm{IJ} \\
\text { line segments are circle diameters, EF } \\
\text { line segments } \\
\text { and GH are not } \\
\text { circular } \\
\text { diameters. } \\
\text { Based on the } \\
\text { description, } \\
\text { write in your } \\
\text { own language } \\
\text { what is meant by the center and diameter } \\
\text { of the circle! }\end{array}$ & $\begin{array}{l}\text { Based on the description, write in your own } \\
\text { language what is meant by the center and } \\
\text { diameter of the circle! }\end{array}$ \\
\hline
\end{tabular}

In question number 1, students still have difficulty in describing the ideas specified in the problem because they do not understand well about the concept of bowstring and areas that can be drawn and model images that are suitable for getting relevant solutions. In problem number 2 , students still have difficulty in writing down the definitions of elements that have been identified by their own language. The way to overcome this learning obstacle is to provide a stimulus in the form of questions/statements true/false to students so that students can be directed to define themselves about the elements of the circle. The existence of a "definition column" in the module to provide opportunities for students to redefine the elements of the circle that have been learned using their own language and discuss with friends to share with each other the definitions that have been prepared by each student. In addition, a "creation column" is also provided in the module for students to train students in communicating various possibilities from an explanation of an idea and provide opportunities for students to present their ideas, as well as the teacher's direction to determine the relevant solution of a circle problem through discussion small group. 
Table 2. Learning Obstacle Related to Circumference and Area of the Circle

\begin{tabular}{lll}
\hline Number & \multicolumn{1}{c}{ Didactical Situation } & \multicolumn{1}{c}{ Didactic Anticipation } \\
\hline 3 & $\begin{array}{l}\text { A bicycle wheel has a radius of } 21 \mathrm{~cm} . \\
\text { When the bicycle is paddled, the wheel } \\
\text { rotates } 50 \text { times. Determine the } \\
\text { circumference and distance traveled by } \\
\text { the bicycle wheel! }\end{array}$ & $\begin{array}{l}\text { A bicycle wheel has a radius of } 21 \mathrm{~cm} . \\
\text { When the bicycle is paddled, the wheel } \\
\text { traveled by the bicycle wheel using the } \\
\text { circumfeence formula relationship! }\end{array}$ \\
$\begin{array}{l}\text { A pool is known as a circle. If the } \\
\text { distance of a pole that is right in the } \\
\text { middle of the pond to the edge of the } \\
\text { pool is } 14 \text { meters, determine the surface } \\
\text { area of the circle-shaped pond! }\end{array}$ & $\begin{array}{l}\text { A pool is known as a circle. If the distance } \\
\text { of a pole that is right in the middle of the } \\
\text { pond to the edge of the pool is } 14 \text { meters as } \\
\text { illustrated in the sketch below. }\end{array}$
\end{tabular}

In problem number 3 above, students still have difficulty in connecting the real situation to calculate the distance traveled by the wheel based on the circumference that has been calculated previously. So there are some students who are only able to answer around the wheel without the distance from the wheel based on the given situation. In problem number 4, students still have difficulty in identifying the known elements in real situations, namely the error in setting the radius in diameter based on the real situation given. The way to overcome these various learning obstacles is to remind them of the concept of distance and circumference in daily life through question and answer. The teacher also gives direction to students to link concepts that are known to the real situation through questions and answers and a series of materials in the module. The existence of giving some pictures of the real form of the elements of the circle in the module. The teacher also provides a variety of real situations in the form of drill exercises on a series of module materials.

Table 3. Learning Obstacle Related to Determine the Relationship of Angle at Circle

\begin{tabular}{|c|c|c|}
\hline Number & Didactical Situation & Didactic Anticipation \\
\hline \multirow[t]{3}{*}{5} & Shown $\angle A O B=30^{\circ}, \angle C O D=120^{\circ}$, & Shown $\angle \mathrm{AOB}=\llbracket 30 \rrbracket^{\wedge \circ}, \angle \mathrm{COD}=\llbracket\left(120 \rrbracket^{\wedge \circ}, \mathrm{AB}=15 \mathrm{~cm}\right.$. \\
\hline & $\begin{array}{l}\mathrm{AB}=15 \mathrm{~cm} . \text { Calculate the arc length by } \\
\text { completing the following fields. }\end{array}$ & $\begin{array}{l}\text { Calculate the arc length by completing the following } \\
\text { fields.Value } \angle \mathrm{AOB}=\ldots \text { dan Value } \angle \ldots=\ldots,\end{array}$ \\
\hline & $\begin{array}{l}\text { Value } \angle \ldots=\ldots \\
\text { dan Value } \angle \ldots= \\
\ldots \text {, then the CD arc } \\
\text { length can be } \\
\text { calculated using the }\end{array}$ & $\begin{array}{l}\text { then the } \mathrm{CD} \text { arc length can be } \\
\text { calculated using the arc length } \\
\text { relationship with } \\
\text { namely............., }\end{array}$ \\
\hline
\end{tabular}




\begin{tabular}{|c|c|c|}
\hline Number & Didactical Situation & Didactic Anticipation \\
\hline & arc length relationship with $\ldots$ & Value $\angle \ldots \quad$ arc length $\ldots$ \\
\hline & namely as follows. & $\overline{\text { Value } \angle \ldots}=\overline{\text { arc length } \ldots . .}$ \\
\hline & & $\cdots=\frac{\cdots}{}$ \\
\hline & Value $\angle \ldots$ arc length $\ldots$ & $-\ldots=\overline{\text { arc length } C D}$ \\
\hline & $\overline{\text { Value } \angle \ldots}=\overline{\text { arc length } \ldots . . .}$ & 1 \\
\hline & $\cdots=\frac{\cdots}{m}$ & $\frac{-1}{4}=-$ \\
\hline & $\ldots$ arc length $\mathrm{CD}$ & \\
\hline & $\frac{\cdots}{\cdots}=\frac{\cdots}{\cdots}$ & $\begin{array}{c}\text { arc length } \ldots=\ldots \text { sehingga, arc length } \ldots \text { is } \ldots \\
\qquad \mathbf{c m}\end{array}$ \\
\hline & $\ldots=\ldots$ & \\
\hline & $\begin{array}{c}\text { So that, } \quad \ldots \quad \text { is } \ldots \\
\text { So, the relationship between the central }\end{array}$ & $\begin{array}{l}\text { So, the relationship between the central angle and the } \\
\text { arc length can generally be written as }\end{array}$ \\
\hline & angle and the arc length can generally be & value of central angel-... $\quad \ldots$ \\
\hline & written as & $=\overline{\text { arc lenght ke }-\ldots}$ \\
\hline & $\ddot{\cdots}=\underline{\cdots}$ & \\
\hline
\end{tabular}

In problem above, students still have difficulty in compiling arguments to determine the relationship of the center angle with the arc length, and determine the generalization of the relationship of the center angle and the length of the circle arc based on the steps of the previous settlement. The way to overcome these various learning obstacles is to provide guidance to students to develop generalizations from the concept of a circle through discovery guided by the "let's find" activity and help students to establish relevant generalizations through discussions between students regarding the results of the generalization that has been done.

\subsection{Result Validation of Learning Materials on Circle Based on Mathematical Communication}

One way to find out whether a module that is designed to be feasible or not to use is to do a validation test by the validator. The indicators used in this module validation cover several aspects, namely aspects of relevance, adequacy, completeness of presentation, systematics of presentation, student-centered orientation, linguistics, Bruner's learning theory, and mathematical communication. Below is presented the validation results of the module by the validator in Table 4 .

Table 4. Result of Validation Expert

\begin{tabular}{ccc}
\hline Validator & Percentage Validation & Criteria Validation \\
\hline Validator 1 & $96 \%$ & Very Valid \\
Validator 2 & $78 \%$ & Valid Enough \\
Validator 3 & $90 \%$ & Very Valid \\
Validator 4 & $93 \%$ & Very Valid \\
\hline Average & $89 \%$ & Very Valid \\
\hline
\end{tabular}

Based on the results of the validation of the four experts, the average percentage of $89 \%$ with the validation level is very valid so the circle module based on mathematical communication is appropriate to be used in mathematics learning with small revisions. The 
suggestions for improvement of the validator for the module are described in the following explanation. Validator 1 , the criteria for learning materials are very valid and provide suggestions for presenting more creative questions in the module. Validator 2, it is obtained that the criteria for learning materials are quite valid and provide suggestions for multiplying practice questions per sub-chapter, presenting real pictures related to the active phase, and completing indicators of mathematical communication skills in all exercises and questions in the module. Validator 3, the criteria for learning materials are very valid and provide suggestions to correct some errors in the use of words in the module. Furthermore, Validator 4, the criteria for learning materials are very valid and provide suggestions for adding non-routine questions to sample questions and exercises and updating illustrations that are not clear.

\subsection{Result Validation of Learning Materials on Circle Based on Mathematical Communication}

After the module is revised based on advice from experts, then the circle module based on mathematical communication is tested for practicality. Aspects used in the module practicality test include aspects of ease, aspects of time efficiency, and aspects of benefits. The module practicality test was carried out by a junior high school mathematics teacher and 15 students from Majalengka 6 State Middle School. The following module practicality results are presented in Table 5.

Table 5. Result of Validation Expert

\begin{tabular}{ccc}
\hline Subject & Percentage Practicality & Criteria Practicality \\
\hline Average Practicality by Teachers & $93 \%$ & Very Practical \\
Average Practicality by Students & $89 \%$ & Very Practical \\
\hline
\end{tabular}

Based on the calculation of the percentage of module practicality test by the teacher and students, the average percentage is $93 \%$ and $89 \%$ so that the practicality of the module is very practical. Calculation of the percentage of the practicality of learning materials for teachers in each aspect and obtained a result of $95 \%$ in terms of convenience, $100 \%$ in the aspect of time efficiency, and $83 \%$ in aspects of benefits. Thus, facilitation aspects are very practical criteria, time efficiency aspects are very practical criteria and aspects of benefits are very practical criteria. While the calculation of the percentage of practicality for students in each aspect and obtained a result of $91 \%$ in the convenience aspect, $82 \%$ in the aspect of time efficiency, and $88 \%$ in aspects of benefits. Thus, facilitation aspects are very practical criteria, time efficiency aspects are very practical criteria, and benefits aspects are very practical criteria.

\subsection{Learning Trajectory of Circle Material}

Based on the analysis of learning obstacle in the circle material, the learning trajectory design (learning trajectory) needs to be done as a reference in learning circle material. Trajectory learning is a certain learning path that is facilitated through a series of learning activities according to students' abilities. The preparation of learning trajectory has the potential to bring up an alternative presentation of learning materials that are more in line with the needs of students because they have considered the various thinking processes of students (Dedy \& Sumiaty, 2017). Through this approach, the didactic concept of the circle concept is arranged in the hope that students can understand the concept as a whole in order to minimize the learning obstacle that occurs when students go through the learning trajectory. In the preparation of the learning trajectory, there is the term main 
concept and pressure point. The main concept shows a common thread of concepts in circle material. While the pressure point is an important point of the main concept that makes the flow of learning flow or does not cause jumping thinking. This is so that the learning material presented is in line with a series of didactic situations, namely the pattern of student-material relations through the help of teacher presentations developed on students' learning trajectory. Trajectory learning of circle material is grouped into three types, namely learning trajectory material of circle elements, learning trajectory of material around an area of the circle, and learning trajectory of the material relation between center angle, arc length, and circle area of the circle which are presented in the following figure.

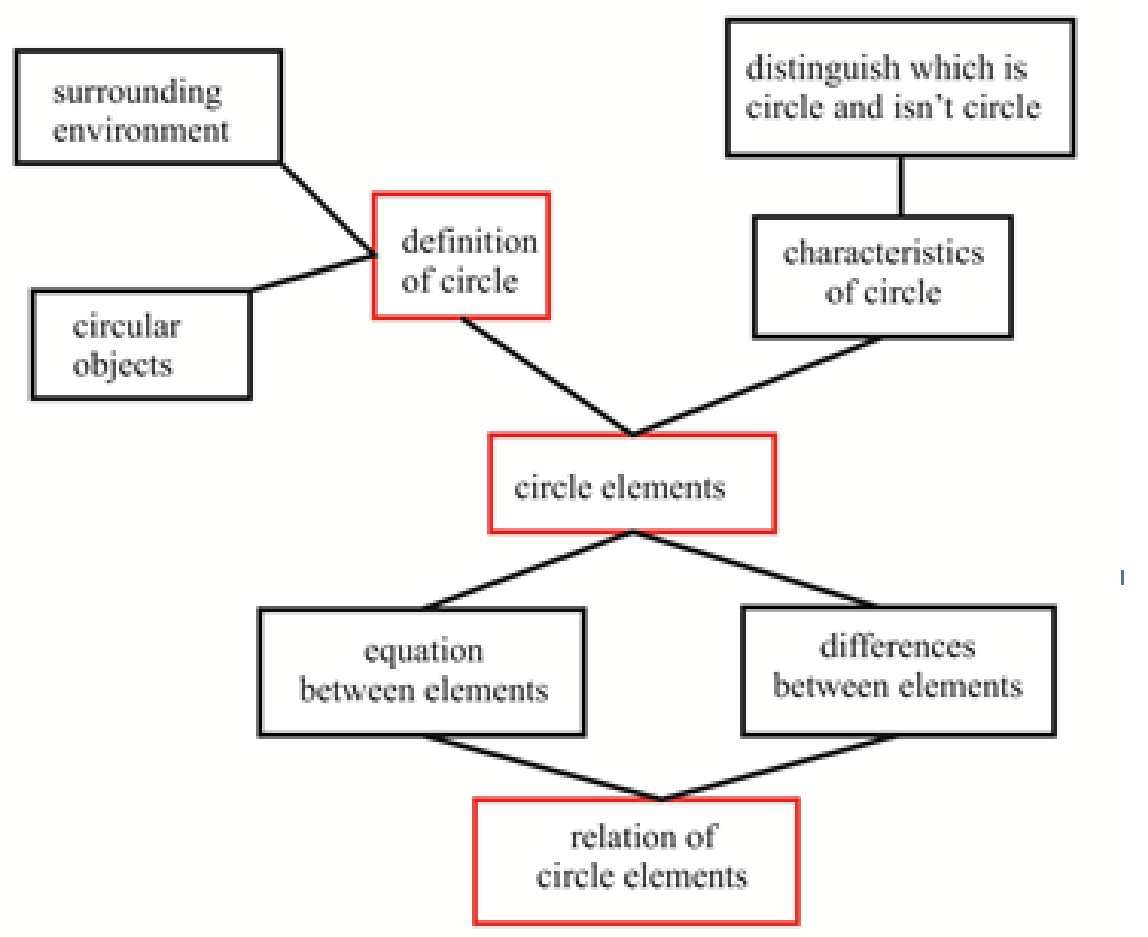

notes :

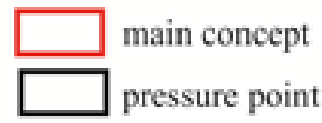

Figure 1. Learning Trajectory Related Circle Element

Learning trajectory to understand the elements of a circle begins by giving students the opportunity to observe the surrounding environment related to the shape of a circle. Next, students express their own language about the definition of a circle in a section accompanied by several reasons for their observations. When students are able to define themselves appropriately, students identify similarities and differences from circular and non-circular objects so that circle characteristics and circle elements can be found. Students learn to find forms of relationships between elements of circles based on their own observations. 


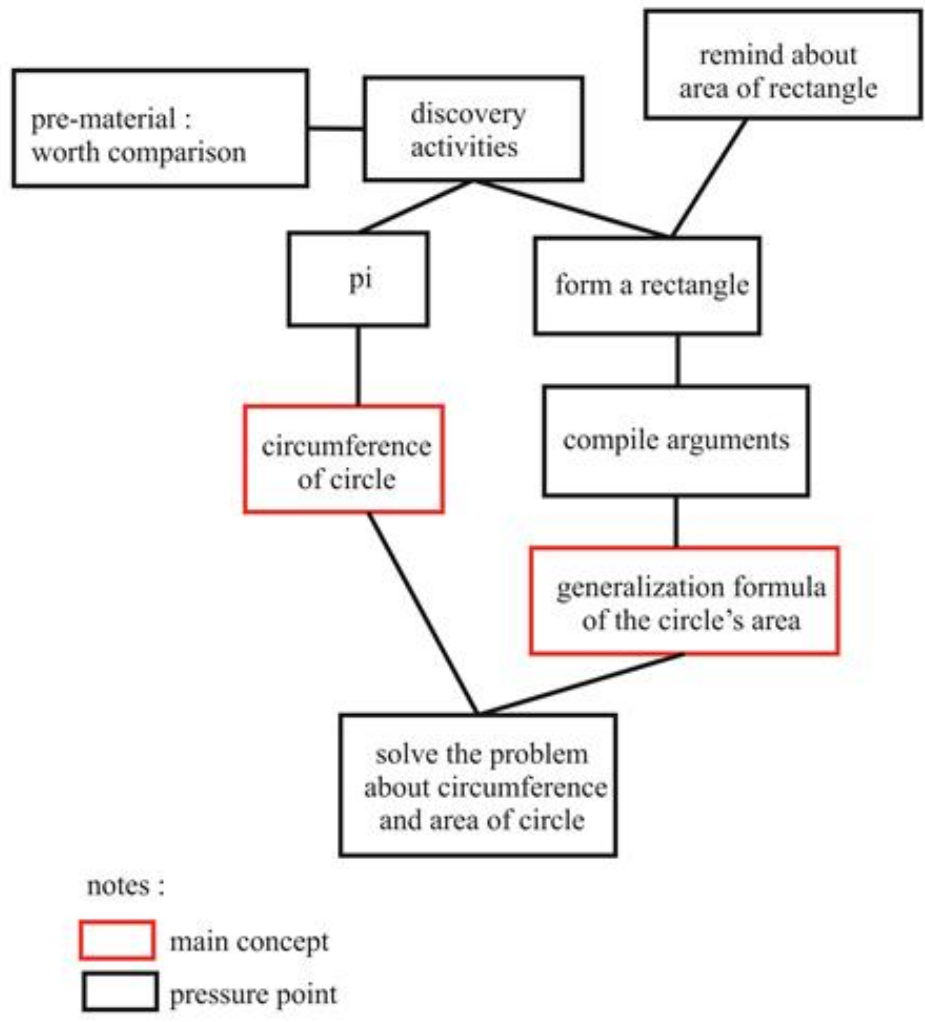

Figure 2. Learning Trajectory Related Circumference and Area of Circle

In this learning trajectory the process of understanding students towards the concept of circumference and the area of a circle is built through discovery activities that are associated with the concept of comparative values and the area of rectangles.

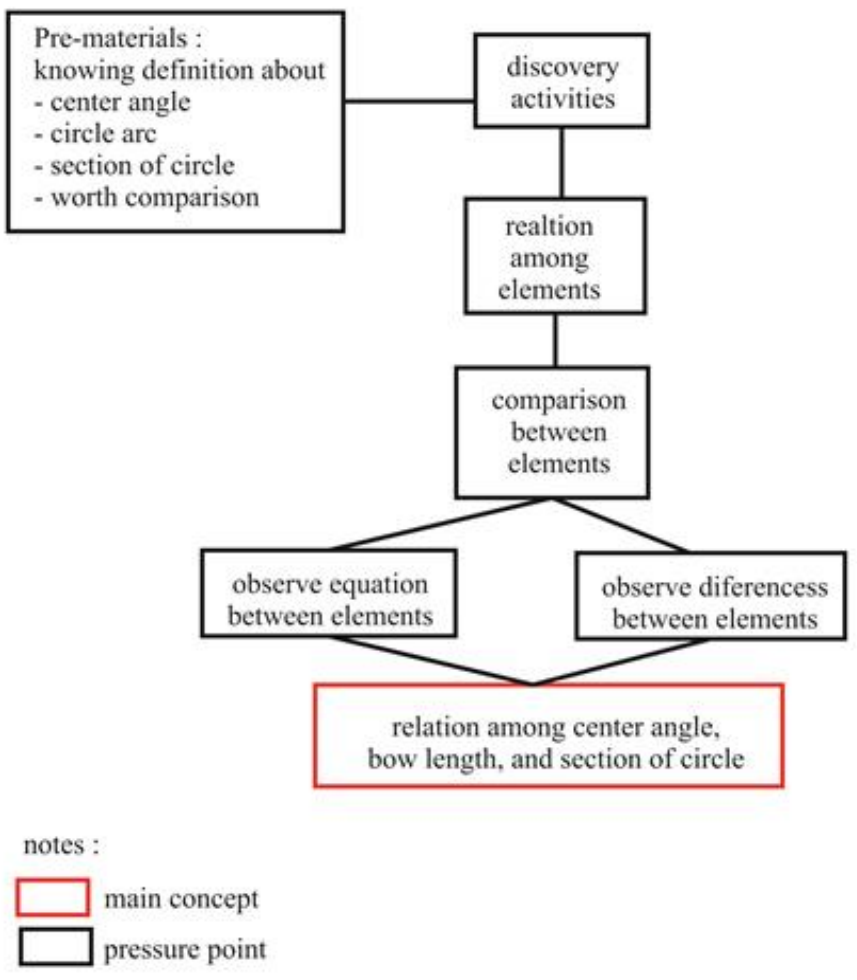

Figure 3. Learning Trajectory Related Relation of Center Angle, Bow Length, 
The student learning trajectory in understanding the concept of the relationship between central angles, arc length, and circle circle area is carried out through the process of discovery by involving students' understanding of the concept of comparable worth as prerequisite material.

The three learning trajectories that are built in understanding students in circle material are based on constructivism and brunner learning theories. The effort was made to create a learning community for students through the process of rediscovering. Based on the results of the study of Johar, Patahuddin, \& Widjaja (2017) that contextual problems may be used to examine students' interest in problems and motivating students to work on it. This is in line with the opinion of Hwang et al. (2007) that learning activities in which there are problem solving, discussing each other and providing responses among fellow students, can improve the ability to express mathematical ideas with various forms of representation. Linking the prerequisite material to the concepts students will learn is in line with Hung (1997) who states that in learning, students need to be motivated and guided by instructors to construct their own ideas, concepts, and understandings based on the prior knowledge they already have. Martin, et al. (2005) emphasize that a set of mathematical understandings is an understanding obtained when a group of students work together in completing mathematical tasks. Development of knowledge through observation and discovery is intended to add to the learning experience of students. Jonassen (2010) explains, one of the factors that influence students' ability to solve problems is prior experience. The prior experience role for a problem solver as a basis for interpreting the problem, provides signs about what should be avoided and predicts the consequences of decisions or actions taken. This is in line with the meaning of full learning according to von Glasersfeld \& Steffe (1991) that meaningful learning will not be realized only by listening to lectures from the instructor, meaningful learning experiences for students can be given one of them through teaching assignments that are more oriented to students' thinking abilities, and students who also do the thinking process.

\section{CONCLUSION}

Based on the results of the analysis that has been done, it can be concluded that at the stage of didactic situation analysis before learning produces a learning obstacle experienced by students is an epistemological type of learning obstacle. The learning obstacle that occurs in the circle material is the related learning obstacle, defining the elements of the circle with their own language. Based on the results of the validation of the four experts, the validation level is very valid so the circle module based on mathematical communication is appropriate to be used in mathematics learning with small revisions. Meanwhile, at the metapedadidactic stage, the results of the module practicality test obtained by the teacher and students obtained very practical module criteria, so that the module is easy to use, useful, and the time used becomes more efficient in mathematics learning. Researchers also compiled learning trajectories related to circle material including learning trajectory material circle elements, learning trajectory material around and wide circle, as well as learning trajectory material relationship between center angle, arc length, and circle circumference area. This trajectory learning can be used as a reference in studying circle material to facilitate the diversity of student learning trajectories. 


\section{REFERENCES}

Abdussakir, A. (2012). Pembelajaran Geometri Sesuai Teori Van Hiele. Madrasah: Jurnal Pendidikan dan Pembelajaran Dasar, 2(1).

Baroody, A. J., \& Coslick, R. T. (1993). Problem solving, reasoning, and communicating, K-8: Helping children think mathematically. Prentice Hall.

Dedy, E., \& Sumiaty, E. (2017). Desain didaktis bahan ajar matematika SMP berbasis learning obstacle dan learning trajectory. JRPM (Jurnal Review Pembelajaran Matematika), 2(1), 69-80.

Greenes, C., \& Schulman, L. (1996). Communication processes in mathematical explorations and investigations. PC Elliott and MJ Kenney (Eds.).

Hiebert, J. (2003). What research says about the NCTM standards. A research companion to principles and standards for school mathematics, 5-23.

Hung, D. W. L. (1997). Meanings, contexts, and mathematical thinking: The meaningcontext model. The Journal of Mathematical Behavior, 16(4), 311-324.

Hwang, W. Y., Chen, N. S., Dung, J. J., \& Yang, Y. L. (2007). Multiple representation skills and creativity effects on mathematical problem solving using a multimedia whiteboard system. Journal of Educational Technology \& Society, 10(2), 191-212.

Johar, R., Patahuddin, S. M., \& Widjaja, W. (2017). Linking pre-service teachers' questioning and students' strategies in solving contextual problems: A case study in Indonesia and the Netherlands. The Mathematics Enthusiast, 14(1), 101-128.

Jonassen, D. H. (2010). Learning to solve problems: A handbook for designing problemsolving learning environments. Routledge.

Martin, T. S., McCrone, S. M. S., Bower, M. L. W., \& Dindyal, J. (2005). The interplay of teacher and student actions in the teaching and learning of geometric proof. Educational Studies in Mathematics, 60(1), 95-124.

Munawaroh, N., Rohaeti, E. E., \& Aripin, U. (2018). Analisis Kesalahan Siswa Berdasarkan Kategori Kesalahan Menurut Watson dalam Menyelesaikan Soal Komunikasi Matematis Siwa SMP. JPMI (Jurnal Pembelajaran Matematika Inovatif), 1(5), 993-1004.

Noto, M. S., Pramuditya, S. A., \& Fiqri, Y. M. (2018). Design of learning materials on limit function based mathematical understanding. Infinity Journal, 7(1), 61-68.

Rosita, C. D. (2016). The development of courseware based on mathematical representations and arguments in number theory courses. Infinity Journal, 5(2), 131-140.

Rosita, C. D., Nopriana, T., \& Dewi, I. L. K. (2017). Bahan Ajar Aljabar Linear Berbasis Kemampuan Pemahaman Matematis. Unnes Journal of Mathematics Education Research, 6(2), 266-272.

Sulistiawati, S., Suryadi, D., \& Fatimah, S. (2015). Desain Didaktis Penalaran Matematis untuk Mengatasi Kesulitan Belajar Siswa SMP pada Luas dan Volume Limas. Kreano, Jurnal Matematika Kreatif-Inovatif, 6(2), 135-146.

Tiffani, F., Surya, E., Panjaitan, A., \& Syahputra, E. (2017). Analysis Mathematical Communication Skills Student At The Grade IX Junior High School. IJARIIE-ISSN (O)-2395-4396, 3. 
Suryadi, D. (2013). Didactical design research (DDR) dalam pengembangan pembelajaran matematika. In Prosiding Seminar Nasional Matematika dan Pendidikan Matematika, 3-12.

von Glasersfeld, E., \& Steffe, L. P. (1991). Conceptual models in educational research and practice. The Journal of Educational Thought (JET)/Revue de la Pensée Educative, 91-103.

Walle, J. A., \& Jhon, A. (2001). Geometric Thinking and Geometric Concepts. Elementary and Middle School. Mathematics: Teaching Developmentally, 4th ed. Boston: Allyn and Bacon. 